\title{
Perspectives in Primary Care: Knowing the Patient as a Person in the Precision Medicine Era
}

\author{
Roy C. Ziegelstein, MD, MACP \\ Department of Medicine, Johns Hopkins University School of Medicine, Baltimore, Maryland \\ Ann Fam Med 2018;16:4-5. https://doi.org/10.1370/afm.2169.
}

$\mathrm{T}$ The patient-physician interaction has changed. Physicians spend much of their time at the computer, examining radiographic images and laboratory test results and documenting in the electronic health record. While most patients express satisfaction with the use of computers in the clinical setting, a recent study noted that, "Patients also cited poor screen positioning, body positioning and eye contact as factors contributing to perceptions of decreased quality of care and unbalanced focus, with the physician appearing more focused on the computer than the patient."1

Patients may sometimes feel left out when interacting with physicians in what some describe as a "no me" experience (personal observation). In 2011, the Schwartz Center for Compassionate Healthcare conducted a national poll of 800 recently hospitalized patients and 510 physicians about aspects of the patient-physician interaction. Importantly, $85 \%$ of patients and $76 \%$ of physicians indicated that compassionate care is "very important" to successful medical treatment and $81 \%$ of patients and $71 \%$ of physicians believed that good communication and emotional support can even make a difference in whether a patient lives or dies. ${ }^{2}$ Patients and doctors agreed that an important aspect of compassionate care is to "treat you as a person, not just a disease."

Wen and Tucker surveyed 51 individuals recruited from coffee shops, metro stops, senior centers, and community centers in Washington, DC. ${ }^{3}$ The authors found that people prioritize what they termed "soft skills" of doctors. They highlighted the importance of

Conflict of interest: author reports none.

\section{CORRESPONDING AUTHOR}

Roy C. Ziegelstein, MD, MACP

Johns Hopkins University School of Medicine

Miller Research Building, 733 N. Broadway, Suite 115

Baltimore, MD 21205

rziegel2@jhmi.edu having a doctor who listens, cares, and explains issues. People valued characteristics and behaviors in physicians that make them feel that their doctor knows them as an individual. Although patients want doctors who "know me," only $42 \%$ of 39,090 patients surveyed by Consumer Reports rated their doctor "excellent" for having "made efforts to get to know me as a person."4

With the advent of precision medicine, the personal nature of the relationship may be even further strained. ${ }^{5}$ While the advances made possible by genomics, pharmacogenomics, proteomics, metabolomics, and other "-omics" offer great promise, unless knowing the patient as a person is considered part of precision medicine, it may be difficult to deliver personalized care, a term referring to "a more holistic approach to healthcare." ${ }^{15}$ This approach is not at all inconsistent with precision medicine. Indeed, Victor McKusick, who many consider the founding father of medical genetics, recognized the importance of knowing the patient as a person to the care of the patient when he noted, "... Osler would be delighted with the concept of individualized medicine and by the possibilities for recognizing individual genetic predispositions provided by knowledge of the genome. ... Osler would emphasize also dimensions of patient uniqueness not directly defined simply by the genome sequence but no less important in the care of the patient. Call them the psychosocial or even spiritual dimensions." ${ }^{\prime \prime}$

Biological and genetic variability make us unique as individuals ${ }_{i}$ however, the person's environment, psychosocial context, social determinants of health, support received from family and friends, and the individual's response to, and experience of, illness have typically been left out of the precision medicine discussion. ${ }^{7}$ One approach to ensure that the patient will be known as a person in the precision medicine era and that the patient-physician interaction will move from a "no me" to a "know me" experience would be to consider genomics, proteomics, metabolomics, and other "-omics" separately from knowing the patient as a person, an approach that might be called "personal- 
Table 1. Knowing the Patient as an Individual

\begin{tabular}{|c|c|c|}
\hline Content Area ${ }^{11,12}$ & Thought Questions ${ }^{11,12}$ & Sample Question or Phrase \\
\hline $\begin{array}{l}\text { The patient as an } \\
\text { individual }\end{array}$ & $\begin{array}{l}\text { How does the condition affect the } \\
\text { patient? How do the patient's circum- } \\
\text { stances and experiences affect the } \\
\text { condition and treatment? }\end{array}$ & "Tell me about yourself." \\
\hline $\begin{array}{l}\text { The patient's life } \\
\text { circumstances }\end{array}$ & $\begin{array}{l}\text { How do the patient's domestic, social, } \\
\text { and work situation and previous } \\
\text { experience of health care impact the } \\
\text { condition, self-management, and life- } \\
\text { style choices? }\end{array}$ & $\begin{array}{l}\text { "What do/did you do for work?" } \\
\text { "What do you like to do in your } \\
\text { free time?" } \\
\text { "Describe your previous relation- } \\
\text { ships with physicians and what } \\
\text { you are hoping for in a doctor- } \\
\text { patient relationship with me." }\end{array}$ \\
\hline $\begin{array}{l}\text { The patient's } \\
\text { concerns }\end{array}$ & $\begin{array}{l}\text { How do the patient's health beliefs, } \\
\text { concerns, and preferences affect } \\
\text { engagement with treatment? }\end{array}$ & $\begin{array}{l}\text { "Please tell me your questions } \\
\text { and concerns." }\end{array}$ \\
\hline $\begin{array}{l}\text { The patient's } \\
\text { needs }\end{array}$ & $\begin{array}{l}\text { How does the patient's need for psy- } \\
\text { chological, social, spiritual and/or } \\
\text { financial support affect treatment? }\end{array}$ & $\begin{array}{l}\text { "Tell me about your family and } \\
\text { who is important in your life." }\end{array}$ \\
\hline $\begin{array}{l}\text { Don't make } \\
\text { assumptions }\end{array}$ & $\begin{array}{l}\text { What assumptions are you making based } \\
\text { on the patient's appearance or other } \\
\text { personal characteristics that may affect } \\
\text { your diagnosis or treatment decisions? }\end{array}$ & \\
\hline
\end{tabular}

also true about the techniques involved with understanding each patient as a person, ie, with the science of "personomics," and more research is needed to develop best practices in this area. This will only be accomplished if personomics is viewed as being essential in order to appropriately apply an understanding of the patient's genetic and biological individuality to the care of the patient and in that way to move from "no me" to "know me" in the precision medicine era.

To read or post commentaries in response to this article, see it online at http://www.AnnFamMed.orgl content/16/1/4. ized medicine without the omics." ${ }^{18}$ This fails, however, to recognize that knowing the patient as a person is what allows physicians to use an understanding of the patient's genetic and biological uniqueness to provide maximum benefit to the patient. Today's society, today's learners, today's physicians, and today's patients generally equate the "-omics" of precision medicine with hard science, ${ }^{9}$ and hard science with value. If we treat the process of getting to know patients as individuals as requiring "soft skills," ${ }^{13}$ we imply it has less value than "-omics" typically considered in the discussion of precision medicine. Instead, the skills involved in developing an appreciation of the unique circumstances of the person - what can be thought of as the personome-are as important for physicians to learn and practice as the skills involved in understanding and applying knowledge of the individual's genome, epigenome, proteome, pharmacogenome, and metabolome. ${ }^{10}$

Physicians and physicians-in-training must be taught the most effective, efficient, valid, and reliable techniques to understand each individual's psychological, social, cultural, behavioral and economic situation and how it impacts the person's experience of health and illness. They must learn what questions to ask to understand each patient's values and goals, health beliefs, and personal preferences. Questions that may be asked during the patient interview that may help physicians get to know their patients as individuals are shown in Table 1, derived from studies of this topic. ${ }^{11,12}$

The science of genomics, proteomics, and other "-omics" is still in its infancy and the power that each will have in allowing future physicians to provide individualized care to patients has not yet been realized. This is
Submitted March 19, 2017; submitted, revised, May 27, 2017; accepted June 29, 2017.

Key words: precision medicine; personalized care; communication and precision medicine

\section{References}

1. Lee WW, Alkureishi MA, Ukabiala O, et al. Wroblewski, Arora VM. Patient perceptions of electronic medical record use by faculty and resident physicians: a mixed methods study. J Gen Intern Med. 2016;31(11):1315-1322.

2. Lown BA, Rosen J, Marttila J. An agenda for improving compassionate care: a survey shows about half of patients say such care is missing. Health Aff (Millwood). 2011;30(9):1772-1778.

3. Wen LS, Tucker S. What do people want from their health care? A qualitative study. J Particip Med. 2015;7:e10.

4. American Medical News. http://www.amednews.com/article/20070129/profession/301299967/2/. Accessed Feb 2, 2017.

5. Cornetta K, Brown CG. Balancing personalized medicine and personalized care. Acad Med. 2013;88(3):309-313.

6. McKusick V. Oslerian Medicine in the Age of Genomics. Convocation Address, Honorary Doctorate, McGill University, May 2006.

7. Collins FS, Varmus $\mathrm{H}$. A new initiative on precision medicine. N Engl J Med. 2015;372(9):793-795.

8. Kravitz RL. Personalized medicine without the "omics". J Gen Intern Med. 2014;29(4):551.

9. Baker M. Big biology: the 'omes puzzle. Nature. 2013;494(7438): 416-419.

10. Ziegelstein RC. Personomics. JAMA Intern Med. 2015;175(6):888-889.

11. National Clinical Guideline Centre (UK). Patient experience in adult NHS services: improving the experience of care for people using adult NHS services: patient experience in generic terms. London: Royal College of Physicians (UK). Feb 2012.

12. Hanyok LA, Hellmann DB, Rand C, Ziegelstein RC. Practicing patient-centered care: the questions clinically excellent physicians use to get to know their patients as individuals. Patient. 2012;5(3): 141-145. 